above, and will see many smart movements imposed upon the seal by the clever internal 'architecture' of the tank. This fine basin recalled the modest accommodation which the seal living in the Heligo. land aquarium many years ago had to be content with.

As with the Station of former times, the very appropriate speech from Goethe is in evidence. It now faces us set into the wall in large bronze capitals as we enter through the main public door: "Alles ist aus dem Wasser Entsprungen, alles wird durch das Wasser erhalten, Ozean gönn uns Dein ewiges Walten".

It was due to the kind generosity of the Bund Ministry that I was able to attend the impressive re-opening. For those who would know very much more about the new Biologische Anstalt Helgoland, a full account written by its director exists ${ }^{1}$ and a shorter one by one of his assistants ${ }^{2}$.

${ }^{1}$ Bückmann, A., Helgol. Wiss. Meeresunters., 7, Heft 1, 1-50 (Han-

${ }^{2}$ Hempel, (4., Die Cmschau, 12, 353-4 (Frankfurt am Main, 1959).

\title{
OBITUARIES
}

\section{Prof. E. Percival}

A GREAT blow has been dealt to marine and freshwater biology in New Zealand by the death on July 15, in Christchurch, of Prof. Edward Percival. Prof. Pereival, who was born in 1893, was elected to the chair of biology at Canterbury University College, as it was then called, in 1928 after serving as lecturer in the Department of Zoology at the University of Leeds, where he was assistant to the late Prof. Walter Garstang. During 1928 he worked as a temporary naturalist in the Plymouth Laboratory on the ecology of the Rivers Tamar and Lynher, and he will be well remembered by those who knew him then. The son of a Cheshire farmer, Percival spent his boyhood in Lancashire, where he took the national diploma in agriculture at the Harris Institute, Preston, and he found much to interest him when he came to New Zealand. His early work on the ecology of rivers in Yorkshire led him to play a prominent part in trout management in acclimatiza tion society work in New Zealand, and his experience in marine biology in the United Kingdom was put to good use in guiding his research students and in advising the policies of various government depart. ments.

His published work, amounting only to about a score of papers, is not a sufficient criterion by which to judge the man. He had declined various academic honours since he maintained that such things were of no use to him. He did, however, consent to be elected a Fellow of the Royal Society of New Zealand.

First and foremost he was a teacher. From the elementary - to the postgraduate-level he never failed to bring out the best in the human material set before him. His particular philosophies on the teaching and appreciation of biology will be long remembered by all those who came in contact with him, even if only as incidental associates.

For his advanced students he held a twice-yearly field expedition to Menzies Bay, one of the isolated little coves on Banks Peninsula, and he took his students into the field on almost every other weekend during term, bringing a certain spartan approach to the pleasures of animal observation which helped one more fully realize what is meant by ecology. His aim was to produce, at the postgraduate-level, a student well balanced in outlook, able to think, not to be a storehouse of facts but to know where to turn to find what is already known, and potentially ible to go on in almost any field of biological encleavour. How successful he has been in this can be seen by the wide distribution of his honours students in various positions throughout the world.
The informal, and often quite unzoological, discussions which he held in the field and in the wellremembered atmosphere of his rooms, together with his novel methods of allowing notes to be taken into the examination room, all helped to bring out what powers of expression and thought were available in his students. Indeed, he often remarked that he wished he could conduct his examinations in the University library, for he would know even more easily the worth of his candidates.

Physically he was outstanding for a man near retirement, and in the field his stride and energy in every activity proved more than a match for even the most athletic of his followers.

At the first encounter he presented a rather forbidding aspect and was inclined to be of uncertain temperament, but this, particularly in his later years, was a variation on the theme of not suffering fools gladly. If one genuinely wanted help, advice or encouragement and if one had exercised all one's resources before approaching him, Percival became the proverbial tower of strength and it was difficult not to find oneself being cast in his mould.

Apart from his long-term studies on lakes in the Canterbury foothills and his interests in marine matters, his scientific work will long be remembered for his fine studies on the embryology of the Brachiopoda. Percival was fortunate in having a locality close by where these animals could easily be taken between tides on the rocky shore and he was able to use his advantage to the full in producing his studies on their development and growth. $\mathrm{He}$ was never afraid to admit that he was wrong or that he did not know, an attitude of mind which had its effects particularly on his elementary students contemplating a career in teaching.

Pereival's influence extended far beyond the cloisters of the University of Canterbury, and it would be hard to exaggerate just how widely his teaching and stimulation have been, and will continue to be, felt.

Elliot W. Dawson

\section{Dr. M. R. Schafroth}

Dr. Max Robert Schafroth and his wife, Käthi Schafroth (née Gemperle), died on May 29; they were killed in an aeroplane crash in Northern Queensland, Australia.

Dr. Schafroth was born in Burgdorf, Switzerland, on February 8, 1923. He passed his matriculation at the Gymnasium in Bern in 1949. He then entered the University of Bern in order to study mathematics and physics, later changing to the 
Swiss Federal Institute of Technology in Zurich. He graduated at the latter in 1948, obtaining a diploma in mathematies and physics.

Thereafter he commenced research work under the direction of Prof. W. Pauli, who was professor of theoretical physics at the Institute and Nobel prizewinner of 1944 . Dr. Schafroth obtained his doctorate degree in 1949 and was thereafter appointed as assistant to Prof. Pauli-a post he held until 1253. During that time he continued research in collaboration with Prof. Pauli in quantum field theory and solid state physics.

At this stage the Schweizer Arbeitsgemeinschaft für Mathematik und Physik offered him an overseas travel grant for two years, which he decided to spend in the Department of Theoretical Physics of the University of Liverpool with Prof. H. Fröhlich. After one year in Liverpool, however, he left Europe to accept a lectureship offered him by Prof. H. Messel in the then newly expanded School of Physics at the University of Sydney. He remained at the University of Sydney until his death, having been promoted to a senior lectureship on January 1, 1955, and to a readership on January 1, 1957. In May 1958 he was invited to accept the chair of theoretical physics at the University of Geneva, Switzerland, which invitation he had accepted and intended taking up this post on September 1, 1959 .

Starting mainly with his stay with Prof. Fröhlich in Liverpool, Dr. Schafroth became interested in the theoretical understanding of the phenomenon of superconductivity. This was also his chief research interest during his five years at the University of Sydney. He published several penetrating papers on this subject himself and also inspired contributions from others in the School. There can be no doubt that his work in this field will go down in science as having been a major contribution to the understanding of superconductivity. Several papers by him are yet to appear. These include a review of the field in the series "Solid State Physics", edited by Profs. Seitz and Turnbull.

Apart from this particular field of research, Dr. Schafroth was an expert and inspiring lecturer in the fields of statistical mochanies, solid state physics in general and quantum field theory. He brought into his lectures something of the qualities of his old teacher, Prof. Pauli.

The death of Robert Schafroth and of his wife Käthi will be a great loss to all who knew them.

S. T. Butler

\section{Mr. H. W. Greenwood}

THE death of Mr. H. W. Greenwood occurred on April 30 at the age of seventy-seven. In the course of a very active life, Mr. Greenwood was associated with three industries. Before the First World War he was a mining plant superintendent in the south of Spain. In 1919 he joined Leto Photo Materials Company, manufacturers of photographic paper, and continued with the firm after their amalgamation with Wellington Ward and their later amalgamation with Ilford, Ltd. Since 1937 he had been associated with Powder Metallurgy, Ltd.

Mr. Greenwood wrote profusely in all three subjects, papers and books of a popular but well-informed nature. For many years he was an important con. tributor to the British Journal of Photography.

W. D. Jonks

\section{NEWS and VIEWS}

Electrical Engineering at Newcastle upon Tyne:

Prof. J. C. Prescott

Prof. J. C. Prescotr, professor of electrical engineering at King's College, Newcastle upon Tyne, retires this year. He was elected in 1937, succeeding W. M. Thornton, who was the first holder of the chair. After studying at the University of Liverpool under Prof. E. W. Marchant, he entered a college apprenticeship with the British Westinghouse Company in 1915, continuing later with that Company as research engineer. He saw service with the R.N.V.R. during the First World War, being attached to H.M. Mining School at Portsmouth. After the War, he returned to the University of Liverpool as lecturer in electrical engineering, where he was to remain for 18 years. His early researches were concerned with the behav. iour of constant-current dynamos, and this led by way of a study of the free period of coupled alternators to researches on the inherent instability of parallel connected synchronous electrical machinery. His papers of this period reveal that electrical measurement and measuring instruments were also occupying a substantial part of his time. For this work he was awarded the degree of doctor of engineering by the University in 1931. In Newcastle his research work has been concerned with synchronous governing of alternators, and further studies of the stability of parallel-connected alternators have been made; latterly he has been engaged in an investigation into the performance of turbo/alternator governors, which is still in progress.

The Department of Electrical Engineering at Newcastle has grown greatly in size during Prof. Prescott's tenure of the chair. Under his direction the expansion has been conducted so as to preserve a balance between so-called 'light' and 'heavy current' electrical engineering, and to avoid too early specialization in undergraduate courses. Always playing a large part in the teaching activities of his Department, he has consistently emphasized the necessity for the teaching of fundamentals in university courses, and has always insisted upon the maintenance of a high academic standard in his Honours Sehool. Like his predecessor, he has been active in the affairs of the Institution of Electrical Engineers, being chairman of the North Eastern Centre in 1943-44, and has taken a continued interest in the North East Radio and Measurements Group. Coming from a literary family, he is a man of uncommonly wide interests who holds the respect and affection of all who know him. His friends both inside and outside the University wish him many years of active and happy retirement.

$$
\text { Dr. R. L. Russell }
$$

DR. R. L. RusselL, who has been appointed to the chair of electrical engineering at King's College, Newcastle upon Tyne, in succession to Prof. J. C. Prescott, graduated B.Se. in 1938 and M.Se. in 1939 , 